\title{
Pengaruh pemberian nano daun kelor (moringa oleifera) terhadap kadar mineral serum dan tulang pada tikus sprague dawley jantan tumbuh
}

\author{
Syahrial $^{1 *}$, Rimbawan ${ }^{1}$, Evy Damayanthi $^{1}$, Dewi Apri Astuti ${ }^{2}$, Pipih Suptijah ${ }^{3,4}$
}

\section{ABSTRACT}

Background: One of the important minerals for growth is calcium to build new bone. Moringa oleifera has been known as high nutritional content and bioactive compound tree that could act as antioxidant and improved several diseases like diabetes, arthritis, cardiovascular. Phytochemical analyses have shown that Moringa oleifera contain of high macro minerals like calcium, potasium, magnesium, and phosphor. Several previous studies have shown that mineral nanoparticle have higher bioavailability than natural compounds..

Objectives: The purpose of this study was to analyze the effect of moringa oleifera nanoparticle leaf on mineral serum and bone at growth stage of Sprague Dawley male rats.

Methods: In this study, the pre and post controlled group design and complete random design was used. The subjects were 27 growing male Sprague dawley rats aged 2 month were devided into three group which received standard feed contain $\mathrm{CaCO} 3$ (control group), intervention feed contained 450nm and 750nm nano Moringa oleifera for 60 days. The data of the experiment was analyzed by paired T-test and Duncan test at $95 \%$ confidence level.

Results: The result showed that there was no significance different for both of intervention group for mineral serum and fermur bone. While for the tibia bone, the result showed that the calcium, phosphor and magnesium were significantly increase $(p<0.05)$. The intervention group received 450nm showed more effective improvement of magnesium level $(p<0.05)$ than intervention group received $750 \mathrm{~nm}$.

Conclusion: The intervention of moring a oleifera nanoparticle leaf had a positive effect in decreasing serum and bone mineral levels in male rats. There were significant increased at magnesium level measured in tibia bones after intervention, with higher increasing at group received 450nm nanoparticle.

Keywords : Moringa oleifera; nanoparticle; bone mineral level; serum mineral level

\section{ABSTRAK}

Latar Belakang: Salah satu mineral penting untuk pertumbuhan adalah kalsium untuk membangun tulang baru. Moringa oleifera yang telah dikenal sebagai tanaman yang mempunyai kandungan nutrisi tinggi dan senyawa pohon bioaktif yang dapat digunakan sebagai antioksidan dan menyembuhkan beberapa penyakit seperti diabetes, arthritis, kardiovaskular. Analisis fitokimia menunjukkan bahwa daun dari moringa oleifera mempunyai kandungan mineral seperti kalsium, potasium, magnesium, dan fosfor dengan kandungan tinggi. Beberapa penelitian sebelumnya menunjukkan bahwa nanopartikel mineral memiliki bioavailabilitas lebih tinggi daripada senyawa alami.

Tujuan: Tujuan dari penelitian ini adalah untuk menganalisis pengaruh dari moringa oleifera nanoparticle yang berasal dari daun terhadap serum mineral dan tulang pada tikus Sprague Dawley jantan tumbuh.

Metode: Penelitian ini menggunakan pre and post controlled group design dan metode rancangan acak lengkap (RAL). Sampel yang digunakan di dalam penelitian adalah 27 tikus Sprague dawley jantan tumbuh usia 2 bulan yang dibagi menjadi tiga kelompok yang akan mendapatkan perlakuan pakan standar yang mengandung CaCO3 (kelompok kontrol), umpan intervensi mengandung 450nm dan 750nm nano Moringa oleifera selama 60 hari. Data hasil penelitian akan dianalisia dengan menggunakan paired T-test dan Duncan test pada tingkat kepercayaan 95\%.

Hasil: Hasil penelitian menunjukkan bahwa tidak ada perbedaan yang signifikan untuk kedua kelompok intervensi terhadap mineral serum dan tulang femur. Sedangkan untuk tulang tibia, hasil penelitian menunjukkan bahwa kadar kalsium, fosfor dan magnesium meningkat secara signifikan $(p<0,05)$. Kelompok intervensi yang menerima pakan 450nm menunjukkan peningkatan kadar magnesium yang lebih efektif $(p<0,05)$ dibandingkan kelompok intervensi yang menerima pakan 750nm.

Simpulan: Intervensi nanopartikel dari daun moringa oleifera memiliki efek positif dalam menaikkan kadar mineral serum dan tulang pada tikus jantan tumbuh. Terdapat peningkatan yang signifikan terhadap kadar magnesium yang diukur pada tulang tibia setelah intervensi, dengan peningkatan yang tertinggi terdapat pada kelompok yang menerima nanopartikel 450nm.

Kata Kunci : Kelor; nano partikel; kadar mineral tulang; kadar mineral serum

\footnotetext{
${ }^{1}$ Departmen Gizi, Fakultas Ekologi Manusia, Institut Pertanian Bogor. Jl. Raya Dramaga Kampus IPB Dramaga, Bogor, Jawa Barat 16680

${ }^{2}$ Departemen Ilmu dan Teknologi Pangan, Fakultas Peternakan, Institut Pertanian Bogor. Jl. Raya Dramaga Kampus IPB Dramaga, Bogor, Jawa Barat 16680

${ }^{3}$ Department Teknologi Hasil Perikanan, Fakultas Perikanan, Institut Pertanian Bogor. Jl. Raya Dramaga Kampus IPB Dramaga, Bogor, Jawa Barat 16680

${ }^{4}$ Fakultas Kesehatan Masyarakat, Universitas Andalas. J1. Perintis Kemerdekaan No.94, Jati, Padang Tim., Kota Padang, Sumatera Barat 25128

*Korespondensi : E-mail: abilwawa@ gmail.com, Telp/HP: +6281275689274
} 


\section{PENDAHULUAN}

Pada awal masa pertumbuhan, setiap individu memerlukan asupan gizi yang cukup agar proses pertumbuhan dapat berjalan dengan baik dan sempurna. $^{1,2}$ Salah satu unsur terpenting dalam membantu proses pertumbuhan adalah zat mineral kalsium. ${ }^{3,4}$ Kalsium merupakan mineral paling banyak terdapat dalam tubuh dengan berat sebesar 1,5-2\% dari berat badan orang dewasa yang mempunyai peran untuk mengatur pekerjaan hormon-hormon dan faktor pertumbuhan. Berdasarkan jumlah yang ada, 99\% kalsium berada didalam jaringan keras, yaitu tulang dan gigi. ${ }^{5}$ Kalsium dalam bentuk garam fosfat (yaitu hidroksiapatit) menjaga integritas struktur kerangka selama masa pertumbuhan tulang dan pematangannya, yang terakumulasi dalam kerangka pada tingkat ratarata $150 \mathrm{mg} /$ hari. $^{6}$

Fosfor dan magnesium merupakan salah satu mineral yang memiliki peran penting dalam metabolisme tulang. Fosfor, seperti fosfat bersama dengan ion kalsium akan membentuk hidroksiapatit yang merupakan molekul anorganik utama pada gigi dan tulang. Sedangkan magnesium berfungsi untuk meningkatkan pembentukan Kristal tulang dan kepadatan tulang dengan cara asimilasi kalsium ke dalam jaringan tulang. Magnesium juga mempengaruhi konsentrasi dari kedua hormon paratiroid dan bentuk aktif dari vitamin $\mathrm{D}$, yang merupakan regulator utama homeostasis tulang. ${ }^{\text {. }}$

Salah satu tanaman yang dikenal sebagai tanaman serbaguna adalah tanaman kelor (Moringa Oleifera) yang merupakan spesies dari famili Monogenerik Moringaceae. Tanaman Moringa oleifera atau kelor merupakan tanaman yang berasal dari Himalaya, dan tersebar di beberapa negara seperti Afrika, Amerika Tengah dan Selatan, Sri Lanka, India, Meksiko, Malaysia, Indonesia dan Filipina. Beberapa bagian dari tanaman kelor seperti daun telah diketahui menunjukkan efek antitumor, antiinflamasi, antibakteri, antihelmintik, antioksidan, hipotensif, cardioprotective, efek okular, antiurolitiatik, antipasmodik, hepatoprotective, dan antipiretik. ${ }^{7-10}$ Beberapa mineral yang terdapat di dalam tanaman kelor ini adalah kalsium, magnesium, fosfor. ${ }^{11,12}$ Tanaman kelor mengandung kalsium sebesar $440 \mathrm{mg}$ per $100 \mathrm{~g}$ daun segar dan $2003 \mathrm{mg}$ per $100 \mathrm{~g}$ daun kering. ${ }^{13,14}$ Kandungan kalsium per $100 \mathrm{~g}$ daun kelor dapat mencapai 17 kali lebih banyak dan mempunyai bioavaibilitas 8,79 kali lebih baik dibandingkan dengan susu. Selain itu bubuk daun kelor dalam bentuk kering juga memiliki kadar air sebesar 3,06-3,34\%, lemak $10,2-10,31 \%$, serat $7,29-9,46 \%$, protein 10,74 $11,48 \%$, dan karbohidrat $54,6-57,61 \% .^{11}$

Beberapa penelitian sebelumnya menunjukkan bahwa tanaman kelor memiliki efek positif pada tulang. ${ }^{15,16}$ Ekstrak dari bunga tanaman kelor telah dibuktikan dapat meningkatkan jumlah sel-sel osteoblastik; sedangkan ekstrak dari buah kelor dapat meningkatkan pembentukan tulang yang diinduksi, kandungan hydroxyproline dan pembentukan mineral tulang. ${ }^{15}$ Sedangkan ekstrak dari daun kelor dapat meningkatkan kandungan kalsium pada tulang tikus wistar. $^{16}$

Beberapa tahun terakhir, perkembangan produkproduk nanoteknologi terus meningkat. ${ }^{16}$ Nanopartikel yang secara definisi adalah struktur yang memiliki dimensi ukuran dalam kisaran 1-100 nm semakin hari semakin diakui dalam aplikasi perawatan kesehatan medis. ${ }^{17,18}$ Ukuran nanometer secara signifikan juga dapat meningkatkan bioavailabilitas dari kalsium dan juga memiliki manfaat gizi. ${ }^{19}$ Tingginya bioavailabilitas dari nano kalsium memberikan banyak keuntungan bagi manusia. Nano kalsium dapat difortifikasikan pada bahan pangan sehingga dapat memenuhi kebutuhan kalsium harian orang dewasa sekitar $800 \mathrm{mg} / \mathrm{hari}$ dan dapat dikonsumsi oleh segala usia. ${ }^{20,21}$ Penelitian lain menyebutkan bahwa isolasi dan karakterisasi nano kalsium dari cangkang kijing lokal (Pilsbryoconcha exilis) dengan metode prespitasi dapat menghasilkan partikel nano kalsium dengan ukuran $120-573 \mathrm{~nm} .^{22}$ Kalsium tidak akan dapat diserap tubuh apabila berada dalam bentuk molekul yang besar. Oleh sebab itu diperlukan bentuk ukuran nano pada kalsium agar dapat terserap oleh tulang dengan baik. ${ }^{20}$

Pengolahan daun kelor dalam bentuk serbuk sudah banyak diteliti, akan tetapi penelitian yang mengkaji hubungan antara ukuran partikel daun kelor dan pengaruhnya terhadap absorpsi kalsium pada hewan model dalam masa pertumbuhan masih belum dilakukan. Berdasarkan uraian tersebut diperoleh informasi bahwa kelor (Moringa oleifera) memiliki kadar kalsium (60225 ppm), fosfor (4558 ppm) dan magnesium (765 ppm) yang tinggi. Dengan teknologi nano ukuran partikel serbuk daun kelor dapat diperkecill sehingga diharapkan dapat meningkatkan penyerapan zat gizi terutama kalsium dengan lebih baik. Oleh sebab itu peneliti tertarik untuk melakukan penelitian yang berjudul "Pengaruh Pemberian Nano Daun Kelor (Moringa oleifera) terhadap Kadar Mineral Serum dan Tulang pada Tikus Sprague Dawley Jantan tumbuh (dalam masa pertumbuhan).

\section{BAHAN DAN METODE}

Desain eksperimental yang digunakan di dalam penelitian ini adalah, pre and post controlled group design. Rancangan yang digunakan adalah Rancangan Acak Lengkap (RAL) dengan 3 perlakuan. Penelitian dilakukan pada bulan Maret 2017 hingga November 2017, bertempat di Laboratorium Percobaan Hewan dan Laboratorium Analisis Zat Gizi, Departemen Gizi 
Masyarakat, FEMA IPB, serta Laboratorium Nutrisi ternak daging Fakultas Peternakan IPB. Taraf perlakuan yang diberikan untuk masing-masing kelompok adalah: K-standar yaitu pakan standar didalamnya terdapat 0.5 g CaCO3/ 100 g pakan ukuran $>1000 \mathrm{~nm}, \mathrm{~K}-750$ yaitu pakan standar didalamnya terdapat $23 \mathrm{~g}$ daun kelor ukuran $750 \mathrm{~nm} / 100 \mathrm{~g}$ pakan, dan K-450 yaitu pakan standar didalamnya terdapat $23 \mathrm{~g}$ daun kelor ukuran 450 $\mathrm{nm} / 100 \mathrm{~g}$ pakan.

Bahan yang digunakan dalam penelitian ini adalah pakan tikus yang terdiri atas pakan standar yang mengandung $\mathrm{CaCO} 3$ sebagai sumber kalsium, pakan perlakuan (mengandung nano daun kelor $450 \mathrm{~nm}$ dan $750 \mathrm{~nm}$ ). Hewan model tikus jantan Rattus novergicus dari galur sprague dawley umur 2 bulan pada masa pertumbuhan. Bahan yang digunakan untuk membuat pakan perlakuan standar adalah $\mathrm{CaCO}_{3}(0.5 \%)$ tepung beras $(25 \%)$, casein $(18 \%$ r), minyak (3\%), glukosa (49\%), DL-metionin (0,3\%), CMC (3\%), mineral mix $(0,5 \%)$, vitamin mix $(0,5 \%)$ dan $\mathrm{NaCl}(0,2 \%)$. Pakan perlakuan dibuat dengan mengganti $\mathrm{CaCO} 3$ dan glukosa dengan nano daun kelor ukuran (K-450nm) dan (K-750nm). Peralatan yang digunakan dalam penelitian dibedakan menjadi 4 kelompok, 1) peralatan untuk perawatan tikus, seperti kandang ukuran $36 \times 28 \times 12$ $\mathrm{cm}$ yang dilengkapi dengan kawat kasa yang bisa buka tutup serta wadah tempat makan dan botol minum, serta seperangkat pembersih kandang 2) pembuatan pakan tikus seperti blender dan mixer 3) pengambilan spesimen darah dan organ tikus seperti kapas, alcohol, jarum spuit $5 \mathrm{ml}$ dan peralatan bedah serta tabung EDTA, 4) analisis di laboratorium seperti particle size analyzer (PSA), termometer, spektrofotometer dan atomic absorption spectroscopy (AAS).

Pembuatan Pakan Standar dan Pakan Perlakuan Nano Daun Kelor adalah sebagai berikut : Daun kelor segar yang masih muda (tangkai bagian atas dan tidak termasuk pucuk) dipetik dan dilakukan perontokan, kemudian dilakukan pencucian dengan menggunakan air mengalir, setelah itu disaring dan dikeringkan dengan cara dianginkan pada suhu $30^{\circ} \mathrm{C}$ selama 3 hari. Daun kelor yang sudah kering kemudian dihancurkan dengan menggunakan disc mill sehinggga menjadi serbuk atau tepung daun kelor. Serbuk daun kelor tersebut kemudian di proses dengan metode HEM (High Energy Milling) selama 30 menit, dan diukur partikelnya dengan metode particle size analyzer (PSA) masing masing dengan ukuran $750 \mathrm{~nm}$ dan $450 \mathrm{~nm}$. Setelah bahan tersedia semua kemudian dibuat pakan sesuai jenis pakan.

Sebanyak 27 ekor tikus jantan tumbuh diadaptasikan dengan pemberian pakan standar dan perlakuan serta minum secara ad libitum selama tujuh hari. Setelah masa adaptasi tikus dimasukkan ke dalam kandang, ditempatkan ke dalam ruang dengan masa terang dan gelap masing-masing $12 \mathrm{jam}$, suhu berkisar antara $23,9-26,6^{\circ} \mathrm{C}$ rata rata $\left(25,5^{\circ} \mathrm{C}\right)$ dan kelembaban udara $67-88 \%$ persen (rata-rata $81 \%$ ). Perlakuan diberikan kepada tiga kelompok (masing-masing kelompok terdiri atas 9 ekor tikus), yaitu kelompok pakan standar mengandung $\mathrm{CaCO}_{3}$ dan kelompok perlakuan (pakan mengandung nano daun kelor dengan ukuran 450nm (K-450) dan 750nm (K-750) selama 60 hari. Pemeriksaan serum mineral $(\mathrm{Ca}, \mathrm{P}$, dan $\mathrm{Mg})$ dilakukan sebelum dan setelah perlakuan pada hari ke60 .

Di akhir intervensi, tikus diambil sample darah dari vena kemudian dilakukan operasi pengambilan tulang femur (tulang paha) dan tulang tibia (tulang kering) untuk dianalisis kadar mineralnya $(\mathrm{Ca}, \mathrm{P}$ dan $\mathrm{Mg}$ ) di tulang. Tulang yang sudah preparasi dari hewan model di keringkan pada suhu $60^{\circ} \mathrm{C}$ selama 24 jam kemudian dibersihkan. Tulang yang sudah bersih direndam dengan larutan hydraziniumhydoxid (100\% $\left.\mathrm{N}_{2} \mathrm{H}_{3} \mathrm{OH}\right)$ selama 6 hari, kemudian tulang direndam menggunakan alcohol 50\% selama 1 jam, lalu dibilas menggunakan aquades sebanyak dua kali dan dikeringkan dengan oven $60^{\circ} \mathrm{C}$. Analisis kadar mineral serum kalsium $(\mathrm{Ca})$, fosfor $(\mathrm{P})$ dan magnesium $(\mathrm{mg})$ dengan alat spectrofotometer (menggunakan kit. dengan nomor katalog $10027(\mathrm{P}), 10010(\mathrm{Mg})$ dan 3-249,3250,3-251-3-252 (Ca). Analisis kadar mineral tulang femur dan tibia dengan alat AAS (AOAC 2007).

Seluruh data dari hasil pengamatan ditabulasi dan dibuat dalam bentuk rata-rata dan standar deviasi jika data terdistribusi normal (statistik parametrik) dan median jika data tidak terdistribusi normal (non parametrik). Data untuk parameter mineral serum dan tulang sebelum dan setelah intervensi diuji dengan paired T-test sedangkan pengaruh intervensi terhadap antar kelompok perlakuan dianalisis dengan analisis ragam dengan tingkat kepercayaan 95 persen pada taraf $\alpha=0,05$, dan jika terdapat hasil yang signifikan dilanjutkan dengan uji Duncan. Pengolahan data dilakukan dengan microsoft excel dan program SPSS 23. Penelitian ini sudah mendapat persetujuan Ethical Approval (ethical clearance) dari komite etik hewan penelitian badan penelitian dan pengabdian masyarakat Institut Pertanian Bogor (IPB) dengan nomor 54-2017 IPB.

\section{HASIL}

\section{Perubahan Kadar Mineral Serum (Ca, P, Mg) Tikus Jantan Setelah Perlakuan dengan Nano Daun Kelor Selama 60 Hari}

Hasil penelitian pada Tabel 1 menunjukkan bahwa seluruh perlakuan dapat meningkatkan kadar kalsium $(\mathrm{Ca})$, fosfor $(\mathrm{P})$ dan magnesium $(\mathrm{Mg})$ dalam serum darah tikus jantan tumbuh. Selisih peningkatan kadar Ca serum darah tikus jantan tumbuh lebih tinggi pada perlakuan K-450 dibandingkan K-750 dan K- 
standar meskipun secara statistik tidak signifikan. Perbedaan yang signifikan untuk kadar mineral sebelum dan sesudah perlakuan diperoleh pada perlakuan K- standar untuk $\mathrm{P}$ dan $\mathrm{Mg}(p=0,04)$ dan pada perlakuan $\mathrm{K}-450$ untuk $\mathrm{Mg}(p=0,01)$.

Tabel 1. Perubahan Kadar Mineral Serum (Ca, P, Mg), pada Tikus Jantan Setelah Perlakuan dengan Nano Daun Kelor Selama 60 Hari.

\begin{tabular}{|c|c|c|c|c|}
\hline \multirow{2}{*}{ Parameter } & \multicolumn{3}{|c|}{ Kelompok' } & \multirow{2}{*}{$p^{l)}$} \\
\hline & K-standar \pm SD & K-750 \pm SD & K-450 \pm SD & \\
\hline \multicolumn{5}{|l|}{ Kalsium (mg/dL) } \\
\hline Sebelum & $10,19 \pm 1.48^{\mathrm{a}}$ & $9,60 \pm 1,06^{\mathrm{a}}$ & $10,33 \pm 1,21^{\mathrm{a}}$ & 0,76 \\
\hline Setelah & $11,01 \pm 1.18^{\mathrm{a}}$ & $11,71 \pm 1,43^{\mathrm{a}}$ & $11,71 \pm 1,43^{\mathrm{a}}$ & 0,18 \\
\hline Selisih & $0,81 \pm 2,59^{\mathrm{a}}$ & $2,11 \pm 2,39^{\mathrm{a}}$ & $2,77 \pm 2,14^{\mathrm{a}}$ & 0,62 \\
\hline$p^{2)}$ & 0,64 & 0,26 & 0,16 & \\
\hline \multicolumn{5}{|l|}{ Phospor (mg/dL) } \\
\hline Sebelum & $2,51 \pm 0,89^{\mathrm{a}}$ & $3,91 \pm 2,37^{\mathrm{a}}$ & $3,95 \pm 2,26^{\mathrm{a}}$ & 0,62 \\
\hline Setelah & $5,03 \pm 0,15^{\mathrm{a}}$ & $4,93 \pm 0,14^{\mathrm{a}}$ & $5,15 \pm 0,19^{\mathrm{a}}$ & 0,32 \\
\hline Selisih & $2,52 \pm 0,89^{b}$ & $1,02 \pm 2,50^{\mathrm{a}}$ & $1,20 \pm 2,25^{\mathrm{a}}$ & 0,63 \\
\hline$p^{2)}$ & $0,04 *$ & 0,55 & 0,46 & \\
\hline \multicolumn{5}{|l|}{ Magnesium (mg/dL) } \\
\hline Sebelum & $1,85 \pm 0,21^{\mathrm{a}}$ & $2,16 \pm 0,52^{\mathrm{a}}$ & $1,94 \pm 0,09^{\mathrm{a}}$ & 0,54 \\
\hline Setelah & $2,83 \pm 0,16^{\mathrm{a}}$ & $2,73 \pm 0,21^{\mathrm{a}}$ & $2,82 \pm 0,25^{\mathrm{a}}$ & 0,81 \\
\hline Selisih & $0,99 \pm 0,36^{\mathrm{b}}$ & $0,57 \pm 0,72^{\mathrm{a}}$ & $0,87 \pm 0,16^{\mathrm{b}}$ & 0,57 \\
\hline$p^{2)}$ & $0,04 *$ & 0,31 & $0,01 *$ & \\
\hline
\end{tabular}

Keterangan: $\mathrm{SD}=$ Standar Deviasi; * Signifikan pada $\left.p \leq 0,05 ;{ }^{\mathrm{a}}\right)$ Huruf yang sama pada baris yang sama menunjukkan bahwa tidak ada pengaruh signifikan $(p>0.05){ }^{b}$ ) Signifikan dengan $p \leq 0,05$ (Paired-samples Ttest); $p^{1}$ ) Anova antara kelompok; $p^{2}$ ) Paired-samples Ttest antara sebelum dan setelah intervensi;

Tabel 2. Perubahan Kadar Mineral Kalsium (Ca), Fosfor (P) Dan Magnesium (Mg) Pada Tulang Femur Dan Tulang Tibia Tikus Sebelum Setelah Perlakuan Selama 60 Hari

\begin{tabular}{|c|c|c|c|c|c|c|c|c|}
\hline \multirow[b]{2}{*}{ Parameter } & \multicolumn{4}{|c|}{ Tulang femur } & \multicolumn{4}{|c|}{ Tulang tibia } \\
\hline & $\begin{array}{c}\text { K-Standar } \\
\text { 土SD }\end{array}$ & $\begin{array}{c}\text { K-750 } \\
\pm \text { SD }\end{array}$ & $\begin{array}{c}\mathrm{K}-450 \\
\pm \mathrm{SD}\end{array}$ & $p^{I}$ & $\begin{array}{c}\text { K-standar } \\
\pm \text { SD }\end{array}$ & $\begin{array}{l}\text { K-750 } \\
\pm \text { SD }\end{array}$ & $\begin{array}{c}\text { K-450 } \\
\pm \text { SD }\end{array}$ & $p^{1}$ \\
\hline \multicolumn{9}{|l|}{$\begin{array}{l}\text { Kalsium } \\
(\%)\end{array}$} \\
\hline Sebelum & $32,52 \pm 0,04^{\mathrm{a}}$ & $32,52 \pm 0,04^{\mathrm{a}}$ & $32,52 \pm 1,04^{\mathrm{a}}$ & 1 & $34,39 \pm 0,67^{\mathrm{a}}$ & $34,39 \pm 0,67^{\mathrm{a}}$ & $34,39 \pm 0,67^{\mathrm{a}}$ & 1 \\
\hline Setelah & $33,31 \pm 0,48 a$ & $34,71 \pm 1,76^{\mathrm{a}}$ & $34,45 \pm 1,59^{a}$ & 0,47 & $36,75 \pm 2,00^{\mathrm{a}}$ & $35,87 \pm 0,75^{\mathrm{a}}$ & $37,13 \pm 1,40^{\mathrm{a}}$ & 0,6 \\
\hline Selisih & $0,78 \pm 1,25^{\mathrm{a}}$ & $2,18 \pm 2,17 \mathrm{a}$ & $1,93 \pm 2,30^{\mathrm{a}}$ & 0,67 & $2,35 \pm 2,66^{\mathrm{a}}$ & $1,47 \pm 1,42^{\mathrm{a}}$ & $2,73 \pm 1,64^{\mathrm{a}}$ & 0,74 \\
\hline$p^{2}$ & 0,39 & 0,22 & 0,29 & & 0,27 & 0,22 & 0,1 & \\
\hline \multicolumn{9}{|l|}{$\begin{array}{l}\text { Phospor } \\
(\%)\end{array}$} \\
\hline Sebelum & $19,41 \pm 0,51^{\mathrm{a}}$ & $19,41 \pm 0,51^{\mathrm{a}}$ & $19,41 \pm 0,51^{\mathrm{a}}$ & 1 & $19,66 \pm 0,53^{\mathrm{a}}$ & $19,66 \pm 0,53^{\mathrm{a}}$ & $19,66 \pm 0,53^{\mathrm{a}}$ & 1 \\
\hline Setelah & $19,67 \pm 0,56^{a}$ & $19,16 \pm 0,09^{\mathrm{a}}$ & $19,62 \pm 0,37^{\mathrm{a}}$ & 0.21 & $20,42 \pm 0,44^{\mathrm{a}}$ & $20,02 \pm 0,07^{\mathrm{a}}$ & $20,32 \pm 0,05^{\mathrm{a}}$ & 0,24 \\
\hline Selisih & $0,25 \pm 0,50^{\mathrm{a}}$ & $0,25 \pm 0,59^{a}$ & $0,20 \pm 0,50^{\mathrm{a}}$ & 0.49 & $0,75 \pm 0,54^{\mathrm{a}}$ & $0,36 \pm 0,46^{\mathrm{a}}$ & $0,65 \pm 0,51^{\mathrm{a}}$ & 0,64 \\
\hline$p^{2}$ & 0,47 & 0.54 & 0,56 & & 0,14 & 0,32 & 0,18 & \\
\hline \multicolumn{9}{|l|}{$\begin{array}{l}\text { Magnesium } \\
(\%)\end{array}$} \\
\hline Sebelum & $0,25 \pm 0,06^{\mathrm{a}}$ & $0,25 \pm 0,06^{\mathrm{a}}$ & $0,25 \pm 0,06^{\mathrm{a}}$ & 1 & $0,31 \pm 0,01^{\mathrm{a}}$ & $0,31 \pm 0,01^{\mathrm{a}}$ & $0,31 \pm 0,01^{\mathrm{a}}$ & 1 \\
\hline Setelah & $0,32 \pm 0,01^{\mathrm{a}}$ & $0,35 \pm 0,03^{\mathrm{a}}$ & $0,43 \pm 0,11^{\mathrm{a}}$ & 0.27 & $0,34 \pm 0,01^{\mathrm{a}}$ & $0,41 \pm 0,01^{\mathrm{b}}$ & $0,58 \pm 0,03^{c}$ & 0,00 \\
\hline Selisih & $0,07 \pm 0,07^{\mathrm{a}}$ & $0,10 \pm 0,09^{\mathrm{a}}$ & $0,17 \pm 0,18^{a}$ & 0.63 & $0,03 \pm 0,01^{\mathrm{a}}$ & $0,09 \pm 0,01^{\mathrm{b}}$ & $0,26 \pm 0,03^{\mathrm{c}}$ & $0,00 *$ \\
\hline$p^{2}$ & 0,23 & 0,23 & 0,24 & & $0,01 *$ & $0,01 *$ & $0,01^{*}$ & \\
\hline
\end{tabular}

Keterangan: $\mathrm{SD}=$ Standar Deviasi; * Signifikan pada $\left.p \leq 0.05 ;{ }^{\mathrm{a}, \mathrm{b}, \mathrm{c}}\right)$ Huruf yang berbeda pada kolom menunjukkan ada pengaruh yang signifikan $\left.(p>0.05) ; p^{1}\right)$ Anova antara kelompok; $p^{2}$ ) Paired-samples Ttest antara sebelum dan setelah intervensi;

Perubahan Kadar Mineral Tulang Femur dan Tibia (Ca, P, Mg) Tikus Jantan Setelah Perlakuan Selama 60 Hari dengan Nano Daun Kelor

Analisis mineral selain dilakukan pada serum darah, juga dianalisis pada tulang femur dan tibia hewan coba karena tulang femur dan tibia merupakan tempat deposit mineral. Tabel 2 berisi rerata kadar mineral tulang femur dan tibia dari ketiga kelompok perlakuan sebelum dan sesudah perlakuan. Hasil penelitian pada tikus jantan memperlihatkan 
peningkatan kadar mineral $\mathrm{Ca}$ dan $\mathrm{Mg}$ tulang femur sebelum dan setelah perlakuan.

Peningkatan mineral $\mathrm{Ca}$ tulang femur tertinggi terdapat pada perlakuan K-750 (selisih 2,18), mineral P tulang femur lebih tinggi pada perlakuan standar ( nilai selisih 0,25), sedangkan mineral $\mathrm{Mg}$ tulang femur lebih tinggi pada perlakuan K-450 (selisih 0,17 ). Berdasarkan hasil uji pared t-test tidak terdapat perbedaan yang signifikan terhadap kadar mineral $\mathrm{Ca}, \mathrm{P}$ $\mathrm{Mg}$ pada tulang femur sebelum dan setelah perlakuan pada semua kelompok perlakuan $(p>0,05)$. Hasil analysis of variance juga menunjukkan tidak ada perbedaan kadar mineral $\mathrm{Ca}, \mathrm{P}, \mathrm{Mg}$ tulang femur antar perlakuan baik sebelum maupun setelah perlakuan $(p>0,05)$. Artinya status mineral $\mathrm{Ca}, \mathrm{P}, \mathrm{Mg}$ di serum yang tidak berbeda nyata ternyata berdampak pada status mineral $\mathrm{Ca}, \mathrm{P}, \mathrm{Mg}$ di tulang femur.

Peningkatan kadar mineral $\mathrm{Ca}, \mathrm{P}$ dan $\mathrm{Mg}$ tulang tibia setelah perlakuan, peningkatan kadar mineral $\mathrm{Ca}$ tulang tibia tertinggi terdapat pada perlakuan K-450 (selisih 2,73), mineral $\mathrm{P}$ tulang tibia lebih tinggi pada perlakuan standar( nilai selisih 0,75), sedangkan mineral $\mathrm{Mg}$ tulang tibia lebih tinggi pada perlakuan $\mathrm{K}$ 450 nilai selisih 0,26 . Berdasarkan hasil uji paired t-test terdapat perbedaan signifikan kadar mineral $\mathrm{Mg}$ tulang tibia sebelum dan setelah perlakuan pada kelompok K$450 \quad(p<0,05)$. Hasil analysis of variance juga menunjukkan perbedaan kadar mineral $\mathrm{Mg}$ tulang tibia pada perlakuan $450 \mathrm{~nm}(p<0,05)$.

\section{PEMBAHASAN}

Hasil penelitian dari pemberian nano daun kelor (Moringa Oleifera) pada tikus sprague dawley jantan tumbuh membuktikan bahwa kandungan mineral (kalsium $(\mathrm{Ca})$, fosfor $(\mathrm{P})$, dan magnesium $(\mathrm{Mg})$ ) dari daun kelor yang telah di modifikasi dalam bentuk nano partikel dapat mengoptimalkan kinerja dari kandungan mineral khususnya kandungan kalsium (Ca) dan magnesium $(\mathrm{Mg})$ yang terdapat di dalam daun kelor tersebut, sehingga kandungan mineralnya menjadi lebih mudah terserap oleh tubuh apabila di bandingkan dengan kadar mineral yang terdapat di dalam pakan yang tidak dalam bentuk nano partikel. Dari hasil penelitian pada Tabel 2 menunjukkan bahwa secara perlakuan pakan dengan daun kelor dalam bentuk nano mampu meningkatkan kadar mineral kalsium (Ca), dan magnesium $(\mathrm{Mg})$ lebih besar pada tulang femur dan tibia tikus jantan tumbuh apabila di bandingkan dengan pakan yang tidak di tambahkan dengan daun kelor dalam bentuk nano. Meskipun demikian peningkatan kadar mineral secara signifikan hanya terjadi pada kadar Mg pada tulang tibia. Bila dibandingkan antar perlakuan, maka perlakuan K-450 memberikan selisih peningkatan kadar $\mathrm{Mg}$ tulang tibia yang paling signifikan $(p=0,00)$ dibandingkan K-750 dan K-standar.
Hasil yang ditunjukkan pada Tabel 2 sejalan dengan penelitian Toba et al. (1999) yang menggunakan tikus jantan dengan perlakuan berbagai tingkatan kadar kalsium dan magnesium. Hasil penelitian tersebut menunjukkan bahwa magnesium dan kalsium saling berkompetisi dalam proses penyerapan di dalam usus. Magnesium memberikan efek yang lebih besar pada metabolisme kalsium tulang dibandingkan dengan absorbsi kalsium.Sedangkan unsur fosfor berperan dalam menjaga keseimbangan kadar kalsium dalam darah maupun laju penyimpanan kalsium dalam usus pakan dengan fosfor berlebihan akan dapat menurunkan absorbsi kalsium. Dari data yang diperoleh dari penelitian ini terlihat bahwa bahwa peran $\mathrm{Mg}$ lebih nyata terlihat pada tulang tibia. ${ }^{23}$ Dua proses penyerapan utama ada di usus, yaitu aktif dan pasif transpor aktif pada dasarnya terjadi pada duodenum dan sebagian kecil terjadi di usus besar. Konsentrasi $\mathrm{Ca}$ rendah dan dimediasi melalui produk metabolic vitamin D 1,25-dihidroksikolekalsiferol. ${ }^{24}$ Total efisiensi penyerapan $\mathrm{Ca}$ dengan kondisi fisiologis (lebih tinggi selama pertumbuhan dan masa remaja serta kehamilan tetapi lebih rendah setelah 50 tahun). Biasanya sekitar 30-35\% dari $\mathrm{Ca}$ dalam makanan diserap tetapi bisa lebih tinggi atau lebih rendah, tergantung pada komposisi makanan tetapi juga mungkin pada faktor genetik. ${ }^{25}$

Selain interaksi magnesium dan kalsium, terdapat interaksi antara fosfor dan kalsium. Fosfor berperan dalam menjaga keseimbangan kadar kalsium dalam darah maupun laju penyimpanan kalsium dalam usus pakan dengan fosfor berlebihan akan dapat menurunkan absorbsi kalsium. Kalsium dan fosfor saling berinteraksi dalam proses penyerapan, dimana kalau kondisi kalsium tinggi maka fosfor harus rendah sehingga proses metabolism berjalan dengan optimal, kalau seandainya terjadi sama-sama tinggi maka akan terjadi reabsorpsi, dimana cadangan yang ada pada tulang akan dipakai. Keseimbangan antar kalsium dan fosfor ini diatur melalui sistem fisiologis kompleks yang terdiri dari interaksi hormon kalsitropik seperti hormon paratiroid 1.25-dihydroxycholecalciferol (atau 1.25-dihidroksi-vitamin D3), dan kalsitonin, dengan jaringan target tertentu (ginjal, tulang, dan usus) yang berfungsi untuk meningkatkan atau mengurangi masuknya $\mathrm{Ca}$ ke dalam ruang ekstraseluler. ${ }^{26}$ Sekresi hormon ini diatur sepenuhnya, atau sebagian dengan konsentrasi plasma terionisasi $\mathrm{Ca}$, sehingga membentuk sistem umpan balik negatif. Hormon paratiroid dan 1.25-dihydroxycholecalciferol disekresikan ketika $\mathrm{Ca}$ plasma rendah, sementara kalsitonin disekresikan ketika Ca plasma tinggi. ${ }^{27}$

Selanjutnya Tongchan et al. (2009) yang melakukan penelitian tentang efek pemberian kalsium dari tulang ikan Priacanthu tayenus pada tikus Wistar jantan yang diberi pakan standar dengan kandungan 
kalsium murni selama tujuh minggu menunjukkan hasil bahwa efek dari suplementasi kalsium dapat meningkatkan bioavailabilitas kalsium secara signifikan $(p<0,05)$ dengan peningkatan suplementasi kalsium akan dapat meningkatkan panjang dan tebal tulang femur dengan demikian komposisi penyusun mineral juga meningkat. ${ }^{28}$ Tetapi hasil penelitian yang dilakukan oleh Zvinorora et al. (2015) memperlihatkan bahwa serbuk moringa oleifera dalam bentuk pelet dengan kalsium yang rendah $(0,2 \%)$ yang diberikan selama 5 minggu tidak berpengaruh terhadap massa tulang tibia dan femur tikus. Intervensi kalsium yang rendah berdampak merugikan bagi pertumbuhan tulang, kekuatan tulang, arsitektur tulang, massa puncak tulang dan material tulang. Hal ini disebabkan karena perbedaan dosis, lama intervensi dan ukuran dari bahan yang diberikan. ${ }^{23}$

Penelitian Carinet et al (2013) pada suplementasi pada tikus jantan (usia 28 hari) dengan berbagai tingkatan (tinggi kalsium $(1,2 \%)$, dan $(0,5 \%)$ serta rendah kalsium $(0,2 \%)$ ) yang diberikan selama 4 minggu didapatkan bahwa kalsium yang rendah memiliki dampak yang merugikan pada pertumbuhan tulang, kekuatan tulang, arsitektur tulang, massa puncak tulang dan material tulang, berbeda dengan suplementasi tinggi kalsium yang menunjukkan hasil bahwa suplementasi tinggi kalsium dapat memperbaiki kekuatan, pertumbuhan, dan arsitektur tulang. ${ }^{29}$ Penelitian ini menggunakan berbagai tingkatan dalam pemberian intervensi, sehingga dapat dilihat dosis yang mana lebih baik, yang diberikan selama 4 minggu.

\section{SIMPULAN}

Berdasarkan dari hasil penelitian ini, intervensi dari daun kelor (moringa oleifera) dalam bentuk nano pada semua kelompok mempunyai dampat yang positif terhadap peningkatan kadar mineral serum dan tulang pada tikus jantan tumbuh. Dari ketiga perlakuan yaitu pakan standar, pakan K-750 dan pakan K-450 diketahui bahwa perlakuan K-45 mempunyai efek yang signifikan terhadap kadar magnesium (Mg) dibandingkan dengan perlakuan pakan standard dan pakan K-750. Kadar kalsium (Ca) paling tinggi secara signifikan $(\mathrm{p}<0,05)$ didapatkan pada tulang tibia tikus yang diberikan perlakuan K-450 sedangkan peningkatan kadar mineral secara signifikan pada tulang tibia juga terjadi pada mineral magnesium $(\mathrm{Mg})$ tikus yang diberi perlakuan K-750 ( $\mathrm{p}=0,02$ dan $\mathrm{p}=0,01)$. Perlakuan K-450 memberikan potensi pemanfaatan mineral di tulang yang lebih baik dibanding dengan perlakuan K-750 dan pakan standar.

Perlu penelitian lebih lanjut dengan durasi intervensi lebih lama dengan tujuan agar proses deposit mineral pada tulang dapat terlihat sempurna, selain itu variasi ukuran partikel nano daun kelor agar lebih berpariasi sehingga proses pemanfaatan oleh tubuh lebih maksimal.

\section{UCAPAN TERIMA KASIH}

Ucapan terima kasih diberikan kepada Kementrian Ristek DIKTI melalui program Hibah penelitian disertasi doktor Fakultas kesehatan masyarakat Universitas Andalas, melalui dana penelitian fakultas.

\section{DAFTAR PUSTAKA}

1. Irnani $H$, Sinaga $T$. Pengaruh pendidikan gizi terhadap pengetahuan, praktik gizi seimbang dan status gizi pada anak sekolah dasar. J Gizi Indones. 2017;6(1):58-64.

2. Nuryani, Rahmawati. Kebiasaan jajan berhubungan dengan status gizi siswa anak sekolah di Kabupaten Gorontalo. J Gizi Indones. 2018;6(2):114-22.

3. Komariah A, Alamsyah N. Pengaruh pemberian nano kalsium dari eksoskeleton kepiting bakau (Scylla sp.) selama masa kebuntingan dan laktasi terhadap kekerasan gigi tikus (F1). Seminar Nasional XII Pendidikan Biologi 2015: Prodi Pendidikan Biologi FKIP UNS. Hal 948-952.

4. Dewi NPPA, Susanto H, Rosidi A. Hubungan tingkat kecukupan zat gizi, lean body mass, dan aktivitas fisik dengan kepadatan tulang pada mahasiswa universitas udayana denpasar. J Gizi Indones. 2016;4(2):96 - 101.

5. Amir LR, Suniarti DF, Utami S, Abbas B. Chitosan as a potential osteogenic factor compared with dexamethasone in cultured macaque dental pulp stromal cells. Cell Tissue Res. 2014;358(2):407-15.

6. Almatsier S. Prinsip Dasar Ilmu Gizi. Jakarta: PT. Gramedia Pustaka Utama; 2009.

7. Anwar F, Bhanger MI. Analytical Characterization of Moringa oleifera Seed Oil Grown in Temperate Regions of Pakistan. J Agric Food Chem. 2003;51(22):6558-63.

8. Singh BN, Singh BR, Singh RL, Prakash D, Dhakarey R, Upadhyay G, et al. Oxidative DNA damage protective activity, antioxidant and antiquorum sensing potentials of Moringa oleifera. Food Chem Toxicol. 2009;47(6):1109-16.

9. Ndong M, Uehara M, Katsumata S-i, Suzuki K. Effects of Oral Administration of Moringa oleifera Lam on Glucose Tolerance in Goto-Kakizaki and Wistar Rats. J Clin Biochem Nutr. 2007;40(3):22933.

10. Verma AR, Vijayakumar M, Mathela CS, Rao CV. In vitro and in vivo antioxidant properties of 
different fractions of Moringa oleifera leaves. Food Chem Toxicol. 2009;47(9):2196-201.

11. Gopalakrishnan L, Doriya K, Kumar DS. Moringa oleifera: A review on nutritive importance and its medicinal application. Food Sci Hum Wellness. 2016;5(2):49-56.

12. Chumark P, Khunawat P, Sanvarinda $Y$, Phornchirasilp S, Morales NP, Phivthong-ngam L, et al. The in vitro and ex vivo antioxidant properties, hypolipidaemic and antiatherosclerotic activities of water extract of Moringa oleifera Lam. leaves. J Ethnopharmacol. 2008;116(3):439-46.

13. Oyeyinka AT, Oyeyinka SA. Moringa oleifera as a food fortificant: Recent trends and prospects. J Saudi Soc Agr Sci. 2018;17(2):27-36.

14. Vongsak B, Sithisarn P, Gritsanapan W. HPLC quantitative analysis of three major antioxidative components of Moringa oleifera leaf extracts. Planta Med. 2012;78(11):15.

15. Patel C, Rangrez A, Parikh P. The antiosteoporotic effect of Moringa oliefera on osteoblastic cells: SaOS 2. Int J Pharm Biol Sci. 2013;5(2):10 - 7.

16. Ordzhonikidze CG, Ramaiyya LK, Egorova EM, Rubanovich AV. Genotoxic effects of silver nanoparticles on mice in vivo. Acta Naturae. 2009;1(3):99-101.

17. Faedmaleki F, Shirazi FH, Salarian A-A, Ashtiani HA, Rastegar H. Toxicity effect of silver nanoparticles on mice liver primary cell culture and HepG(2) cell line. Iran $\mathbf{J}$ Pharm Res. 2014;13(1):235-42.

18. Chaloupka K, Malam Y, Seifalian AM. Nanosilver as a new generation of nanoproduct in biomedical applications. Trends Biotechnol. 2010;28(11):5808.

19. Gao H, Chen H, Chen W, Tao F, Zheng Y, Jiang $\mathrm{Y}$, et al. Effect of nanometer pearl powder on calcium absorption and utilization in rats. Food Chem. 2008;109(3):493-8.
20. Suptijah P, Jacoeb AM, Deviyanti N. Karakterisasi dan bioavabilitas nano kalsium cangkang udang vanamei (Litopenaeus vanamei). J Akuntika. 2012;3(1):63-73.

21. Trilaksani W, Salamah E, Nabil M. Pemanfaatan limbah tulang ikan tuna (Thunnus sp.) sebagai sumbar kalsium dengan metode hidrolisis protein. Buletin Teknologi Hasil Perikanan. 2006;9(2):3445.

22. Purwaningsih SP, dan Khoerunisa. Isolasi dan karakterisasi nano kalsium dari cangkang kijing lokal (Pilsbryconcha Exelis) dengan metode presipitasi. Jurusan teknik hasil perikanan Institut Pertanian Bogor. Bogor: Institut Pertanian Bogor. 2012.

23. Toba Y, Masuyama R, Kato K, Takada Y, Aoe S, Suzuki K. Effect of dietary magnesium level on calcium abasorption in growing male rats. Nutr Res. 1999;19(5):783-93.

24. Dorinha MSS, Vitti E, Kebreab E. Phospaharus and calcium nutrition metabolism in: phosparus utilization ang requirement in farm animal. Wallingford, Oxfordshire, UK: CAB International; 2010.

25. Roberfroid MB. Inuline-type fructans food ingredient. Washington (US): CRC. 2005

26. Bronner F, Pansu D. Nutritional Aspects of Calcium Absorption. J Nutr. 1999;129(1):9-12.

27. Cashman KD. Calcium intake, calcium bioavailability and bone health. $\mathrm{Br} \mathrm{J}$ Nutr. 2002;87(S2):S169-S77.

28. Tongchan PP, S. ; Niyomwas, S. ; Thongraung, C. Effect of calcium compound obtained from fish by-product on calcium metabolism in rats. Asian J Food Agro Ind. Bangkok2009. p. 669-76

29. Viguet-Carrin S, Hoppler M, Membrez Scalfo F, Vuichoud J, Vigo M, Offord EA, et al. Peak bone strength is influenced by calcium intake in growing rats. Bone. 2014;68:85-91. 